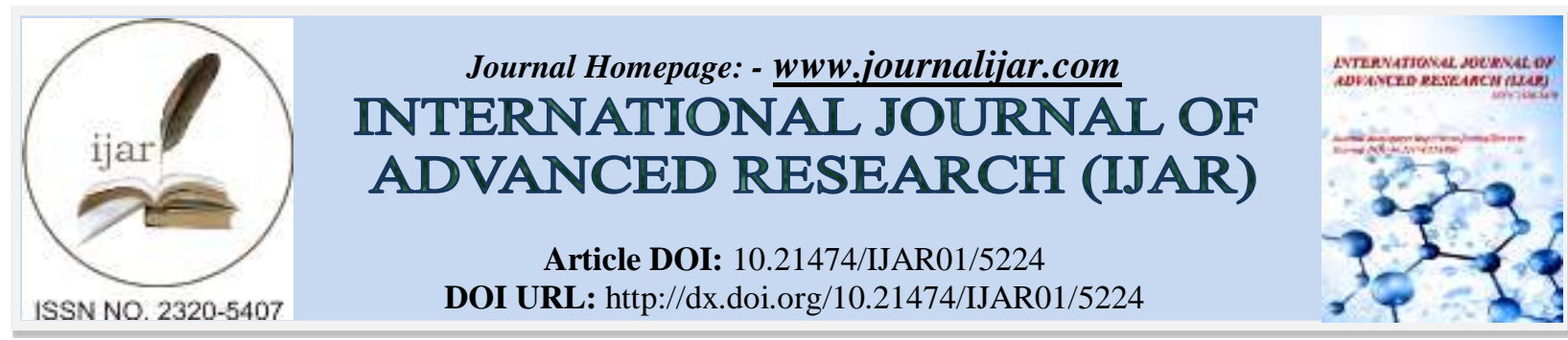

RESEARCH ARTICLE

\title{
PILEA VICTORIAE (URTICACEAE), A NEW STRIKING SPECIES FROM THE MURAL FLORA OF WESTERN GHATS, INDIA.
}

\author{
Sojan Jose ${ }^{1,6}$, ${ }^{*}$ Suresh $V^{1}$, Hareesh $V^{2}$, Robi AJ ${ }^{3}$, Resmy PS ${ }^{1}$, Dinesh Raj $R^{4}$, Asha VV ${ }^{5}$, Prakashkumar R $^{6}$ \\ and Madhusoodanan $\mathbf{P V}^{6}$. \\ 1. Government Victoria College, Palakkad, Kerala, India. \\ 2. Department of Botany, University of Calicut, Kerala, India. \\ 3. Bishop Abraham Memorial College, Thuruthicad, Pathanamthitta, Kerala, India. \\ 4. Department of Botany and Biotechnology, Bishop Moore College, Mavelikkara, Kerala, India. \\ 5. Plant Disease Biology \& Biotechnology, Rajiv Gandhi Centre For Biotechnology, Thiruvananthapuram, Kerala, \\ India. \\ 6. Malabar Botanical Garden and Institute for Plant Sciences, Olavanna, Kozhikode, Kerala, India.
}

\section{Manuscript Info}

Manuscript History

Received: 20 June 2017

Final Accepted: 22 July 2017

Published: August 2017

Key words:-

New species, Pilea, Palakkad,

Urticaceae, Western Ghats.

\section{Abstract}

A new species of Pilea Lindley. from Palakkad gap region of Western Ghats of Kerala is described and illustrated as Pilea victoriae sp. nov. IUCN status, distribution, phenology, phenetic relationships, plastid genome variation and its affinities are discussed.

Copy Right, IJAR, 2017,. All rights reserved.

\section{Introduction:-}

Pilea Lindley (1821) is the largest genus in the family Urticaceae comprising about 715 species (Monro 2004) distributed throughout the tropics, subtropics and temperate regions (with the exception of Australia, New Zealand and Europe). The main revision of the Urticaceae was done by Weddell $(1847,1852)$ and additional treatments were published by Gaudichaud (1830), Bentham \& Hooker (1883), Engler (1894) and Friis (1989). Southeast Asia is the center of morphological and phylogenetic diversity for Pilea whilst the Greater Antilles and Andean countries are the centers of species diversity (Monro 2006). Recently, several new species were described from Central America, Costa Rica and China (Monro 1999, 2000, 2001, 2004,; Monro et al. 2012) and Monro (2006) proposed a phylogenetic framework for the strategic revision of Pilea, based on cpDNA, nrDNA and morphology.

The genus Pilea Lindley is easily distinguished from other Urticaceae members by its opposite leaves with a single ligulate stipule (the latter rarely much reduced or even absent) in each axil and pistillate flowers with a 3-5 parted asymmetrical perigonium. The majority of species are succulent herbs, epiphytes or small shrubs growing in heavy shade at altitudes between 1000 and $3000 \mathrm{~m}$ above sea level (Monro et al. 2012). Within Western Ghats 5 species are recognized (Gamble and Fischer 1923) and all five species are distributed in different geographical regions of Kerala (Sasidharan 2013).

As part of ongoing research on the diversity of flowering plants in Western Ghats of Kerala, S. India, the authors undertook several field trips during 2009-2014. During this the authors observed and collected an interesting species 
of Pilea growing in the Campus of Govt. Victoria College, Palakkad, Kerala. Later the same species was collected from Kollengode and Malampuzha regions of Palakkad district and Perinthalmanna region of Malappuram district. The species shows affinities with the common Pilea, P. microphylla but differs in many attributes. Their affinities are discussed and position within the subdivision of the genus with respect to Weddell (1869) and Chen (1982) is indicated, which although not phylogenetic, is based on the most comprehensive world-wide treatment of the genus.

\title{
Taxonomy:-
}

Pilea victoriae V. Suresh \& Sojan sp.nov. (Fig. 1\& 2)

Diagnosis: Pilea victoriae V. Suresh \& Sojan sp. nov. closely resembling $P$. microphylla but differs and easily distinguished by its erect stem with basal branching, $2-2.5 \mathrm{~mm}$ long ovate stipule, orbicular leaf blade of equal or sub-equal size at each node and pistillate inflorescence bearing 3-22 flowers. (Table 1).

Type:-INDIA, KERALA: Palakkad District, Victoria College Campus, 130 m MSL, (10 47' 4.8804" N; 76 39' 5.8392" E) 07 August 2013, Sojan Jose and V. Suresh 091 (holotype, CALI, isotypes, MH, CMPR, CATH).

Herb to $10 \mathrm{~cm}$; epiphytic or epipetric. Stems prostrate then erect, pale grey-green or pale green-brown, semi transparent, glabrous, the raphides elliptic to punctiform; internodes $2.5-8 \mathrm{~mm}$ long, angulate in cross-section. Stipules $0.3 \mathrm{~mm}$ long, ovate, acute, pale green. Leaves petiolate, opposite, petioles at the same node sub-equal, $2-$ $3.5 \mathrm{~mm}$ long, glabrous; lamina $2-4.5 \times 2-3 \mathrm{~mm}$, orbicular, apex minutely acute, base cuneate, margin entire; upper surface dark green, glabrous, midrib depressed; lower surface pale grey-green, glabrous, glandular, midrib raised, base towards the middle of lamina. Inflorescences 6-15 per stem, unisexual; bracts $0.4-1.0 \mathrm{~mm}$ long; bracteoles $0.5-0.75 \mathrm{~mm}$ long. Staminate inflorescences 1 per axil, $1 \mathrm{~mm}$ long, bearing $2-4$ flowers in a compact head; peduncle $0.4-0.5 \mathrm{~mm}$ long, glabrous; pedicels $0.15-0.2 \mathrm{~mm}$ long, glabrous. Staminate flowers $0.6 \times 0.4-0.5 \mathrm{~mm}$, Pinkish brown; tepals $4,2.5 \mathrm{~mm}$, glabrous, the subapical appendage $0.75 \mathrm{~mm}$, corniculate, glabrous; stamens 4 . Pistillate inflorescences 1 or 2 per axil, 1.5-2 mm long, bearing 14-20 flowers in a compact head; peduncle 1-1.3 mm long, glabrous; pedicels ca. $0.25 \mathrm{~mm}$ long, glabrous. Pistillate flowers $0.75-1.0 \mathrm{~mm}$ long, adaxial tepal $0.675-1.25 \mathrm{~mm}$, oblong, ellipsoid or ovoid, the dorsal tepal appendage ca $0.5 \mathrm{~mm}$, oblong or ovate; the lateral tepals $0.5-0.675 \mathrm{~mm}$, asymmetrically ovate. Infructescence $2-2.5 \times 1-1.5 \mathrm{~mm}$; achenes $0.4-0.5 \times 0.15 \mathrm{~mm}$, compressed, ellipsoid. (Figure 1 $\& 2)$.

\begin{abstract}
Molecular Phylogeny:-
Molecular phylogeny of Pilea has been done previously by Monro (2006), in which he has analyzed the Pilea spp. based on the trnL-F and ITS sequences. To analyze the position of $P$. victoriae in it, ITS gene of $P$. victoriae has been sequenced and the same of the Pilea species has been downloaded from GenBank. The sequences were aligned using multiple sequence alignment tool of the genomics package Geneious (www.biomatters.com) followed construction of the phylogenetic tree using the PHYML plugin for Geneious according to Guindon and Gascuel (2003). Following Monro (2006) Lecanthus peduncularis was used as the out group and the tree has shown that $P$. victoriae has more lineage to $P$. peperomifolia, a Latin American species than that of $P$. microphylla (Figure 3). $P$. victoriae was grouped in a clade that contained $P$. costaricensis, $P$. succulent, $P$. daguensis, in addition to $P$. peperomifolia, whereas $P$. microphylla was included in the clade $P$. spathulifolia and $P$. thymifolia. This clearly established the status of $P$. victoriae as a taxon new to science.
\end{abstract}

Phenology:- Flowering throughout the year under favourable natural conditions.

Etymology:-The species is named after Government 'Victoria' College, Palakkad, Kerala, India in recognition of its more than 125 years of service to the education sector of the state.

Distribution, ecology \& Biotic association:-So far P. victoriae sp. nov. is collected from three different localities of two districts viz. Victoria College Campus, Malampuzha and Nemmara regions of Palakkad district and Perinthalmanna region of Malappuram district, Kerala. Good populations were observed in these areas in an altitudinal gradient 100-200 m. But each population is restricted to a particular area of the collection localities.

Conservation status:- The new species is very common and abundant in these collected localities. More than 12 populations were observed in these 5 localities and a total of around 200-1000 individuals were recorded. According to our current knowledge of and using the IUCN strategies and Criteria (IUCN2012), Pilea victoriae sp. nov. is tentatively classified as Endangered (EN A4ab; B1b(i,ii,iv)+2b(i,ii,iv); C2a(i); E). 

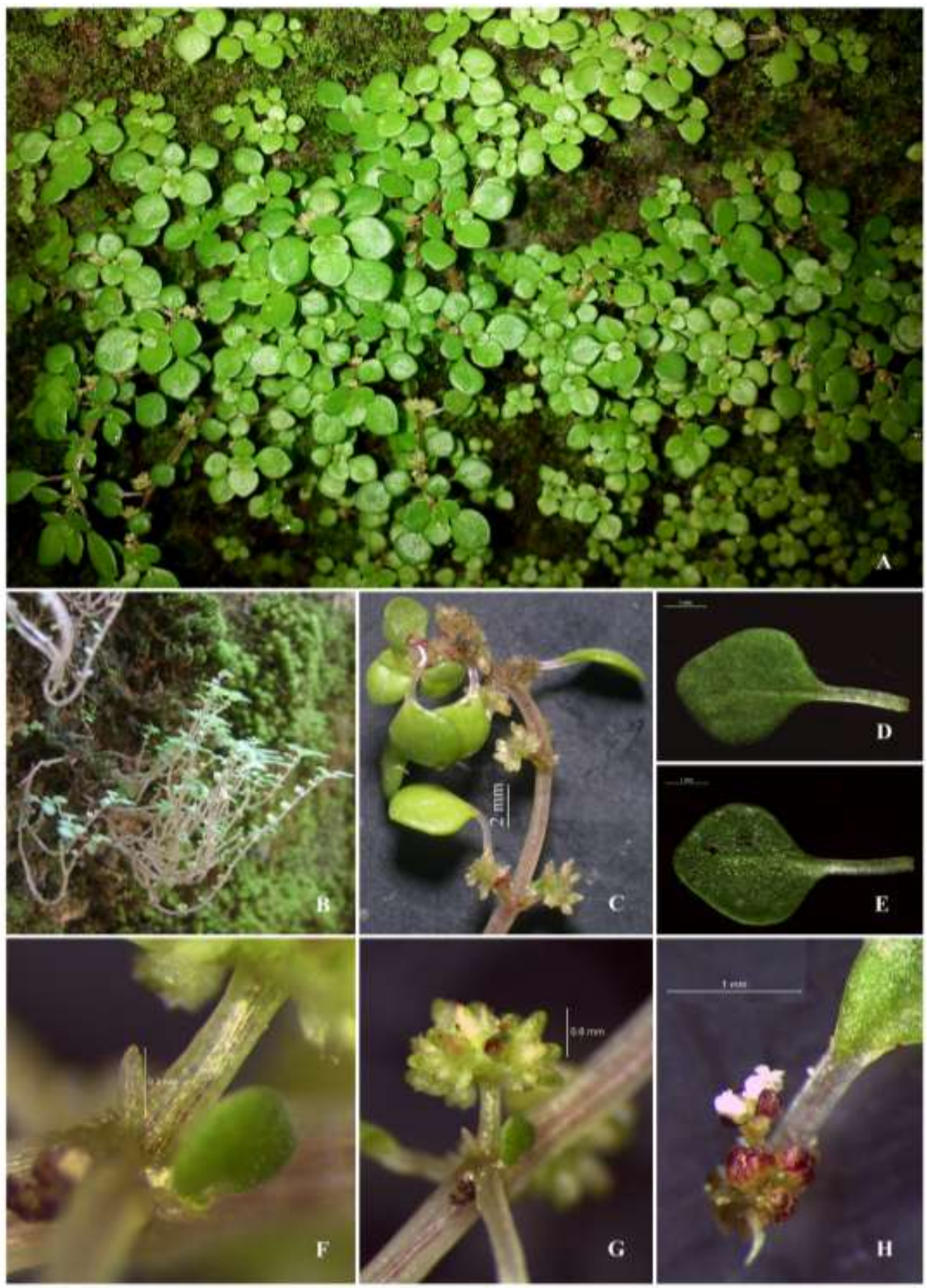

Figure 01:- Pilea victoriae sp. nov. A. Habit; B. Basal branching; C. flowering twig; D. \& E. Adaxial and abaxial views of leaf; F. Stipule; G. Pistillate inflorescence; H. Staminate inflorescence. (Photos: Sojan Jose, Suresh V., Hareesh V.S., \& Robi A.J.) 


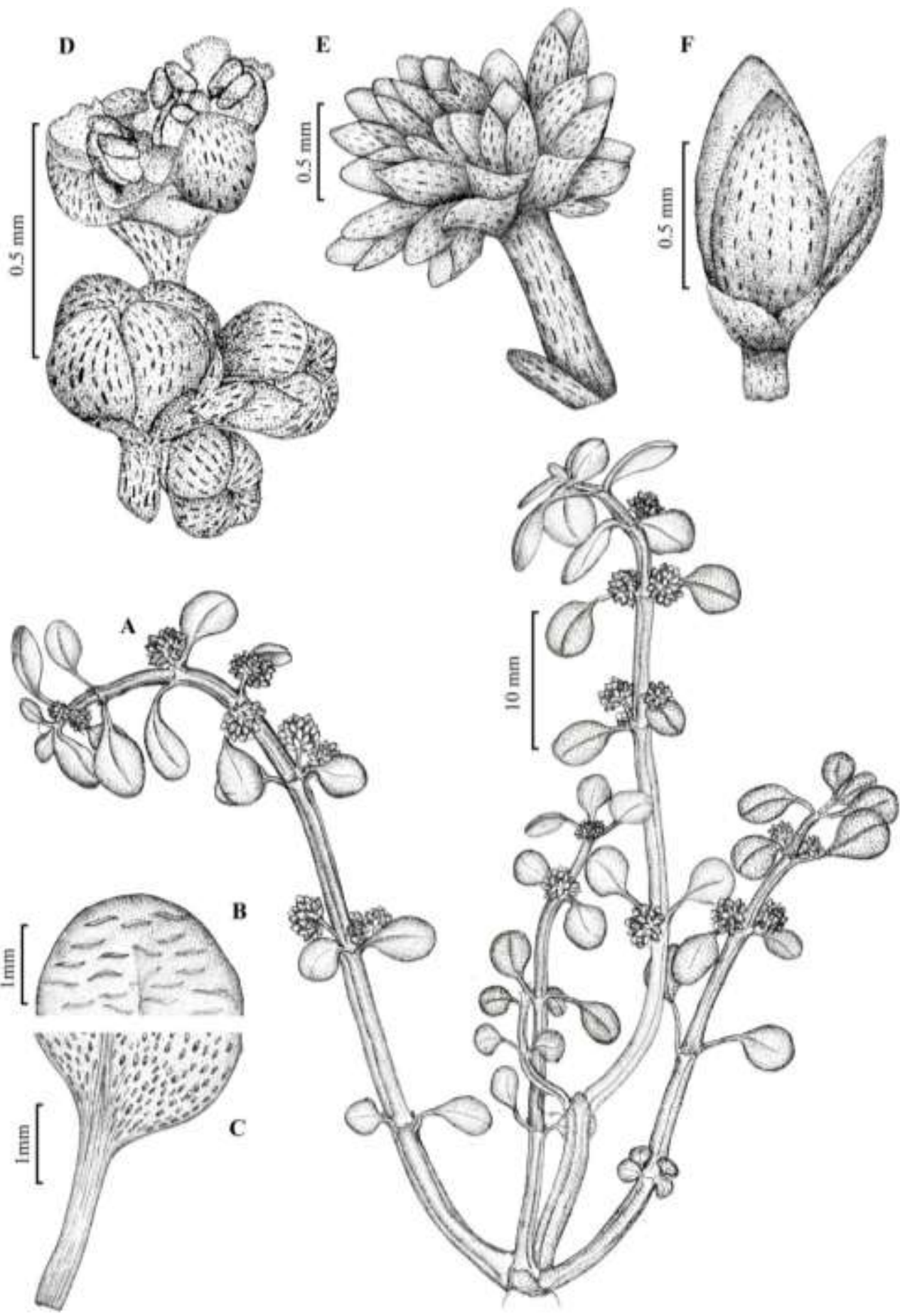

Figure 02:- Pilea victoriae sp. nov. A. Habit; B. \& C. Adaxial and abaxial views of leaf; D. Staminate inflorescence; E. Pistillate inflorescence; F. Capsule. (Drawn after V. Suresh \& Sojan Jose 091 by V.S. Hareesh) 


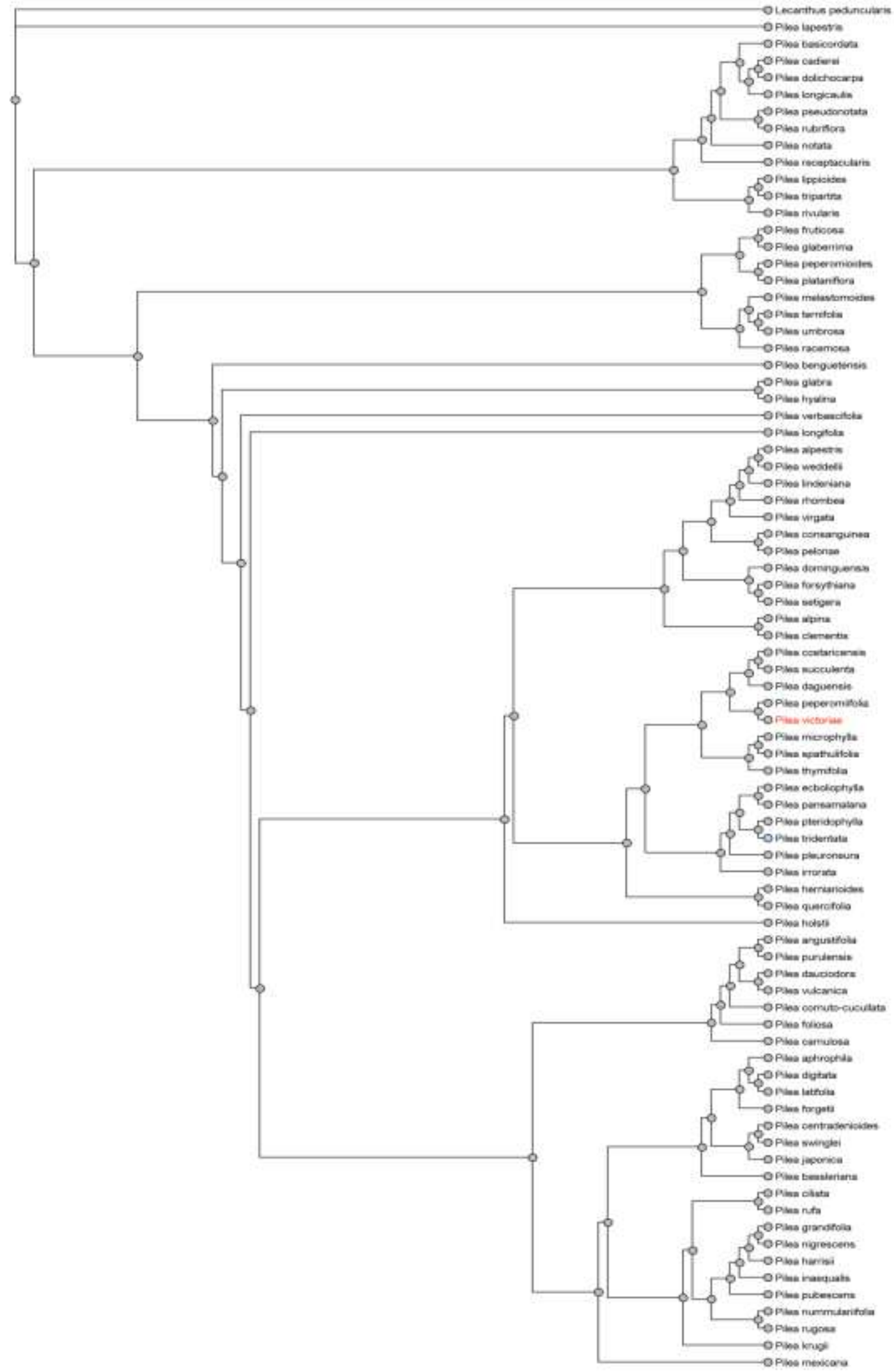

Figure 03:- Molecular phylogeny dendrogram of Pilea spp showing the relative position of Pilea victoriae sp. nov. with respect to other members based on ITS sequence comparison. 
Additional specimens Examined: INDIA. Kerala, Palakkad, Kollengode, 8 August 2011, Sojan Jose \& Suresh V 043 (GVCH!); Sekaripuram, 02 January 2015, Sojan Jose \& Suresh V 105 (GVCH!); Pallavur, 15 September 2014, Suresh V \& Sojan Jose 110 (GVCH!) Malappuram, Thirumanthamkunnu, 28 May 2014, Sojan Jose 186 (GVCH!) (GVCH-Govt. Victoria College Herbarium);

Table 1:- Diagnostic morphological characters of Pilea victoriae with P. microphylla

\begin{tabular}{|l|l|l|}
\hline Character & P. microphylla & P. victoriae \\
\hline Stem nature & Stems drooping or ascending when older & Stem prostrate then erect \\
\hline Internodal branching & Present, very common & Absent or very rare \\
\hline Petiole & Less than 1.5 mm & $2-3.5 \mathrm{~mm}$ long \\
\hline Leaf shape & $\begin{array}{l}\text { Leaf blade elliptic-obovate or spatulate of } \\
\text { unequal size at each node }\end{array}$ & $\begin{array}{l}\text { Leaf blade orbicular of equal or subequal size at } \\
\text { each node }\end{array}$ \\
\hline Stipule & Triangular, 0.5 mm long & Ovate, ca. 0.3 mm long \\
\hline Pistillate inflorescence & Bearing 5-10 flowers & Bearing 14-20 flowers \\
\hline $\begin{array}{l}\text { Lamina length/ breadth } \\
\text { ratio }\end{array}$ & $2-2.7$ & $1.1-1.4$ \\
\hline
\end{tabular}

\section{Acknowledgements:-}

The first and second authors are thankful to the Principal, Govt. Victoria College Palakkad and Dr. Maya C. Nair, Head, Department of Botany for their encouragement and support.

\section{References:-}

1. Bentham, G. \& Hooker, J. D. (1883). Genera Plantarum. Vol. 3. L. Reeve \& Co., London.

2. Chen, C. J. (1982) A monograph of Pilea (Urticaceae) in China. Bulletin of Botanical Research Harbin 2(3): 1132.

3. Engler, A. (1894). Urticaceae. In: A. Engler\& K. Prantl (eds), Die NatürlichenPflanzenFamilien Vol. 3, pp. 98118. Engelmann, Leipzig.

4. Friis, I. (1989). The Urticaceae: a systematic review. In: Evolution, systematics, and fossil history of the Hamamelidae. Volume 2: Higher Hamamelidae. The Systematics Association Special Volume No. $40 B$ : 285 308.

5. Gamble, J. S. \& Fischer, C. E. C. 1923. Flora of the Presidency of Madras. Newman and Adlard, London. (Reprint ed. Vol II, 1957. Botanical Survey of India, Calcutta), pp. 1379.

6. Guindon, S. \& Gascuel, O. (2003).A simple, fast and accurate algorithm to estimate large phylogenies by maximum likelihood. Systematic Biology 52(5):696-704

7. Gaudichaud, C. (1830). Botanique, part 12. In: H. L. C. de Freycinet (ed.), Voyage autour du mondexecutésur les corvettes de S. M. l’Uranieet la Physiciene, pp. 465 - 522 and plates 111-120. Pilet-Ainé, Paris.

8. Hooker, J.D. 1888. Flora of British India, vol. 5: 551. London: Reeve.

9. IUCN. 2012. IUCN Red List Categories and Criteria: Version 3.1. Second Edn.. International Union for Conservation of Nature and Natural Resources. Gland, Switzerland and Cambridge, UK: 1-32.

10. Lindley, J. (1821) Collectaneabotanica, or Figures and botanical illustrations of rare and curious exotic plants. R. \& A. Taylor, London.

11. Monro, A. K. (1999). Seven new species of Pilea Lindley (Urticaceae) from Mesoamerica. Novon 9: 390-400.

12. Monro, A.K. (2000) Three new species of Pilea (Urticaceae) from Costa Rica and Panama. Bulletin of Natural History Museum London, Botany Series 30: 7-11.

13. Monro, A. K. (2001). Synopsis of Mesoamerican Pilea (Urticaceae), including eighteen typifications and a key to the species. Bull. Nat. Hist. Mus. London Bot. 31: $9-25$.

14. Monro, A. K. (2004). Three new species and three new names in Pilea (Urticaceae) from New Guinea. Contributions to the Flora of Mt Jaya XV. Kew Bull. 59: 573 - 579.

15. Monro, A. K. (2006). The revision of species-rich genera: A phylogenetic framework for the strategic revision of Pilea (Urticaceae) based on cpDNA, nrDNA, and morphology. Amer. J. Bot. 93: 426-441.

16. Monro, A. K., Wei, Y. G. \& Chen, C. J. (2012). Three new species of Pilea (Urticaceae) from limestone karst in China. Phytokeys. 19: 51-66.

17. Sasidharan, N. 2013.Flowering plants of Kerala: CD-ROM ver 2.0. Kerala Forest Research Institute, Peechi.

18. Weddell, H. A. (1847). Monographie de la familie des Urticacées. Arch. Mus. Hist. Nat. 9: $1-400$.

19. Weddell, H. A. (1852). Additions à la flore de L'Amérique du Sud: Urticaceae. Ann. Sci. Nat. Paris 3: $197-231$.

20. Weddell, H.A. (1869) In: De Candolle, A., Prodromus, systematis naturalis regni vegetabilis 16(1). Paris. Pp. $104-163$ 